Volume 12, Nomor 2, November 2020, pp 277-293 Copyright (C) 2017

Jurnal Akuntansi, Program Studi Akuntansi, Fakultas Ekonomi, Universitas Kristen Maranatha. ISSN 2085-8698 | e-ISSN 2598-4977. http://journal.maranatha.edu

\title{
Pengaruh Pengetahuan Etika Terhadap Persepsi Etis Mahasiswa Akuntansi Dengan Love Of Money Sebagai Variabel Intervening (Studi Kasus Mahasiswa Program Studi Akuntansi di Lima Perguruan Tinggi Daerah Istimewa Yogyakarta)
}

\author{
Sri Ayem \\ Fakultas Ekonomi-Universitas Sarjanawiyata Tamansiswa \\ Jl. Kusumanegara No. 121, Umbulharjo, Yogyakarta \\ sriayemfeust@gmail.com \\ Loja Dian Evi Leni \\ Fakultas Ekonomi-Universitas Sarjanawiyata Tamansiswa \\ Jl. Kusumanegara No. 121, Umbulharjo, Yogyakarta \\ lojadian93@gmail.com
}

\begin{abstract}
This study aims to examine the effect of ethical knowledge, internship experience, and economic status on the ethical perceptions of accounting students with love of money as an intervening variable. The data used are primary data. The method used is multiple analysis. The sampling technique used in this study was convenience sampling and 90 data samples were obtained. The results of this study indicate that the ethical knowledge variable has a positive effect on the ethical perceptions of accounting students, while ethical knowledge has a negative effect on love of money. love of money has a negative effect on the ethical perceptions of accounting students. Ethical knowledge negatively affects the ethical perceptions of accounting students through love of money as an intervening variable.
\end{abstract}

Keywords : Ethical Knowledge, Ethical Perception, Accounting Student, Love of Money 


\begin{abstract}
Abstrak
Penelitian ini bertujuan untuk menguji pengaruh pengetahuan etika, pengalaman magang, dan status ekonomi terhadap persepsi etis mahasiswa akuntansi dengan love of money sebagai variabel intervening. Data yang digunakan adalah data primer. Metode yang digunakan adalah analisis berganda. Teknik pengambilan sampel yang digunakan dalam penelitian ini adalah convenience sampling dan diperoleh 90 data sampel. Hasil penelitian ini menunjukkan bahwa variabel pengetahuan etika berpengaruh positif terhadap persepsi etis mahasiswa akuntansi, sedangkan pengetahuan etika berpengaruh negatif terhadap love of money. Love of money berpengaruh negatif terhadap persepsi etis mahasiswa akuntansi. Pengetahuan etika berpengaruh negatif terhadap persepsi etis mahasiswa akuntansi melalui love of money sebagai variabel intervening.
\end{abstract}

Kata Kunci: Pengetahuan Etika, Mahasiswa Akuntansi, Persepsi Etis, Love of Money

\section{Pendahuluan}

\section{Latar Belakang Masalah}

Persepsi merupakan cara pandang seseorang yang melibatkan pengetahuan yang dimiliki sebelumnya dalam melihat suatu masalah atau permasalahan. Etika berhubungan dengan pernyataan bagaimana seseorang bertindak terhadap orang lain ( Al, 2010). Seseorang yang memiliki perilaku etis berarti telah mengetahui hal baik, menyukai hal baik, dan melakukan hal baik. Seseorang yang telah mendapat pendidikan etika diasumsikan telah mengetahui hal baik, sehingga memiliki perilaku yang lebih etis dibandingkan orang yang belum mendapatkan pendidikan etika. Persepsi etis adalah bagaimana cara pandang seseorang mahasiswa akuntansi sebagai calon akuntan dengan melibatkan pengalaman dan pembelajaran terhadap etika dari seorang akuntan (Wati, 2016).

Persepsi individu terhadap suatu objek yang sama sangat mungkin memiliki perbedaan yang disebabkan oleh 3 faktor, yaitu faktor pertama pada pemersepsi yang terdiri dari sikap, motif, kepentingan, pengalaman dan pengharapan. Faktor yang kedua dalam situasi terdiri dari waktu, keadaan dan situasi sosial. Faktor yang ketiga pada target terdiri dari hal baru, gerakan, bunyi, ukuran, latar belakang dan kedekatan (Arfan, 2011). Semakin meningkatnya perhatian masyarakat terhadap isu-isu etika dalam dunia bisnis dan profesi maka membuat kepercayaan masyarakat terhadap profesi akuntan menurun. Menurunnya kepercayaan publik terhadap profesi akuntan akan menjadi berdampak pada integritas dan kredibilitas seorang akuntan (Rindayanti, 2017). Dampak tersebut muncul karena kecerdasan dan pengetahuan yang dimiliki akuntan digunakan tanpa berlandaskan norma dan etika dari profesinya (Sugiantari, 2016).

Fenomena pada penelitian ini yang mana sebagai seorang mahasiswa, saya menghabiskan waktu kurang lebih 50\% berada didalam lingkungan kampus. Oleh karena itu, terlihat jelas bahwa terdapat etika-etika tertentu yang terdapat dilingkungan kampus. Meski etika ini sering dilupakan maupun diperhatikan, pada dasarnya etika itu selalu ada dan diajarkan sejak dini dalam lingkungan keluarga, maka dari itu kita menjalankannya antara sadar dan tidak sadar. Akan tetapi, hal ini terkadang berlaku bagi mahasiswa yang kurang mendapatkan pengajaran dasar tersebut. Pada dasarnya mahasiswa sebagai pelaku didalam pergerakan pembaharuan yang akan menjadi generasi-generasi penerus bangsa, membangun bangsa dan 
tanah air ke arah yang lebih baik dituntut untuk memiliki etika. Etika bagi mahasiswa dapat menjadi alat kontrol didalam melakukan suatu tindakan. Etika dapat menjadi gambaran bagi mahasiswa dalam mengambil suatu keputusan. Oleh karena itu, makna etika harus lebih dipahami kembali dan diaplikasikan didalam lingkungan mahasiswa yang realitanya lebih banyak mahasiswa yang tidak sadar dan tidak mengetahui etika dan peran etika itu sendiri (Fatimah, 2017).

Sehingga bermunculan mahasiswamahasiswi yang kurang memperhatikan etika, seperti mahasiswa yang tidak memiliki sopan dan santun kepada para dosen, tidak menyapa, berpakaian tidak senonoh, mahasiswa yang lebih menyukai hidup bebas, mengonsumsi obat-obatan terlarang, pergaulan bebas, berdemonstrasi dengan tidak mengikuti peraturan yang berlaku bahkan hal terkecil seperti menyontek saat ujian dianggap hal biasa padahal menyontek merupakan salah satu hal yang tidak mengindahkan makna dari etika (Fatimah, 2017).

Persepsi etis yang rendah membuat mereka berangggapan bahwa tindakan tidak etis yang mereka lakukan adalah tindakan yang normal. Teori sikap dan perilaku merupakan perilaku seseorang yang ditentukan oleh sesuatu yang orang lain ingin lakukan (sikap), pemikiran tentang apa yang ingin mereka lakukan (aturanaturan sosial), hal apa yang sering mereka lakukan (kebiasaan) serta konsekuensi perilaku apa yang mereka pikirkan (Pradanti, 2014).

Dalam teori sikap dan perilaku menjelaskan bahwa konflik dapat terjadi ketika nilai sikap, aturan-aturan sosial dan kebiasaan seseorang rendah. Padahal persepsi etis menjadi landasan mereka dalam berprilaku karena persepsi etis merupakan sebuah pandangan penilaian seseorang terhadap sesuatu yang yang akan mengarahkan orang tersebut bagaimana dalam bertindak. Ketika persepsi etis seorang mahasiswa rendah, maka perilakunya pun menjadi tidak etis Hal inilah yang patut menjadi perhatian saat ini, kita perlu membentuk kembali persepsi dan pola pikir mahasiswa agar kembali pada perilaku yang berpegangan pada standar etika yang ada, sehingga tercipta lulusan (akuntan) yang profesional dan berintegritas tinggi (Novitasari, 2013).

Berdasarkan kasus tersebut maka pengetahuan mengenai etika harus dilakukan dengan benar kepada mahasiswa akuntansi. Pengetahuan merupakan salah satu cara untuk memahami etika. Salah satu bentuk upaya untuk membekali calon akuntan dengan etika dilakukan oleh International Federation of Accountants (IFAC) dengan mengeluarkan standar pendidikan internasional (International Education Standards/IES) untuk calon akuntan. Standar tersebut mengatur nilai-nilai yang harus diperoleh untuk memenuhi kualifikasi akuntan professional. Nilai tersebut antara lain yaitu nilai profesional, etika dan sikap akuntan profesional. Nilai-nilai ini perlu diberikan dengan tujuan agar calon akuntan dapat mengambil keputusan yang etis sesuai kepentingan masyarakat luas. (Sari, 2018).

Pengetahuan mengenai perilaku benar-salah atau baik-buruk diperoleh melalui pengalaman, pembelajaran dan pendidikan. Melalui pendidikan etika di bangku perkuliahan mahasiswa akan mempunyai karakteristik untuk menjunjung tinggi nilai-nilai etika sebelum memasuki dunia kerja (Sari, 2018). Etika merupakan prinsip moral dan nilai yang diketahui sebagai sesuatu yang baik dan benar. Etika adalah sifat dasar yang harus dimiliki oleh seseorang atau sebuah organisasi sebagai pedoman berperilaku dalam kehidupan bermasyarakat. Pengetahuan merupakan salah satu cara untuk memahami etika. Seseorang yang memiliki perilaku etis berarti telah mengetahui hal baik, menyukai hal baik, dan melakukan hal baik. Seseorang yang telah mendapat pendidikan etika diasumsikan telah mengetahui hal baik, sehingga memiliki perilaku yang lebih 
etis dibandingkan orang yang belum mendapatkan pendidikan etika (Sari, 2018). Penggunaan variabel intervening digunakan dalam penelitian ini karena persepsi etis mahasiswa akuntansi bukan hanya sebagai hasil atau akibat langsung dari pengetahuan etika, pengalaman magang dan status ekonomi melainkan juga ada faktor lain yang memberikan kontribusi terhadap persepsi etis mahasiswa akuntansi yaitu love of money.

Kecintaan seseorang akan uang ( love of money) sering diartikan negative kemudian dianggap tabu oleh masyarakat tertentu. Kecintaan terhadap uang dipandang negative, hal ini karena sebagian orang menganggap uang mampu memberikan kesukaan diatas segalagalanya. Uang merupakan aspek yang sangat penting dalam kehidupan sehari-hari dan seringkali digunakan untuk mengukur keberhasilan seseorang dalam sebuah pekerjaan yang dilakukan (Ernawati, 2016).

Teori harapan didasarkan pada motivasi dalam berperilaku yang akan menghasilkan kombinasi suatu keinginan yang diharapakan sebagai suatu hasil. Orang-orang akan termotivasi untuk melakukan hal-hal tertentu guna mencapai tujuan apabila mereka yakin bahwa tindakan mereka akan mengarah pada pencapaian tujuan tersebut. Teori harapan menjelaskan mengenai motivasi yang dimiliki karyawan untuk mengeluarkan tingkat usaha yang tinggi dengan melakukan kinerja yang baik karena mereka berkeyakinan bahwa kinerja yang baik akan menghasilkan penilaian kinerja yang baik pula (Fatimah, 2017).

Berbeda dengan sebagian masyarakat yang tinggal di pedesaan, hal ini memungkinkan bahwa masyarakat yang tinggal dipedesaan memandang uang bukanlah segalanya, karena nilai uang bagi sebagian masyarakat yang tinggal didesa merupakan pelengkap yang nilainya tidak mensyaratkan akan nilai jual yang tinggi (Kumala, 2016).
Penelitian ini replikasi dari penelitian sebelumnya oleh Ernawati (2016) Determinan Persepsi Etika Mahasiswa Akuntansi Dengan Love Of Money sebagai variabel intervening. Pembeda penelitian ini dengan penelitian sebelumnya, peneliti menggunakan variabel berbeda yang disarankan oleh peneliti terdahulu yaitu pengalaman magang dan status ekonomi. Berdasarkan hal tersebut, maka peneliti melakukan penelitian yang berjudul "Pengaruh Pengetahuan Etika Terhadap Persepsi Etis Mahasiswa Akuntansi Dengan Love Of Money Sebagai Variabel Intervening (Studi Kasus Mahasiswa Program Studi Akuntansi Di Lima Perguruan Tinggi Daerah Istimewa Yogyakarta)".

\section{Perumusan Masalah}

Berdasarkan latar belakang penelitian tersebut, maka rumusan masalah penelitian adalah sebagai berikut:

1. Apakah pengetahuan etika berpengaruh terhadap persepsi etis mahasiswa akuntansi?

2. Apakah pengetahuan etika berpengaruh terhadap love of money?

3. Apakah love of money berpengaruh terhadap persepsi etis mahasiswa akuntansi?

4. Apakah Pengetahuan Etika berpengaruh terhadap Persepsi Etis Mahasiswa Akuntansi melalui love of money sebagai variabel intervening?

\section{Tujuan Penelitian}

1. Untuk mengetahui pengaruh pengetahuan etika terhadap persepsi etis mahasiswa akuntansi.

2. Untuk mengetahui pengaruh pengetahuan etika terhadap love of money.

3. Untuk mengetahui pengaruh love of money terhadap persepsi etis mahasiswa akuntansi.

4. Untuk mengetahui pengaruh Pengetahuan Etika terhadap Persepsi 
Etis Mahasiswa Akuntansi melalui love of money sebagai variabel intervening.

\section{Kerangka Teoritis dan Hipotesis}

\section{Teori Sikap dan Perilaku (Theory of Attitude and Behaviour)}

Teori sikap dan perilaku merupakan perilaku seseorang yang ditentukan oleh sesuatu yang orang lain ingin lakukan (sikap), pemikiran tentang apa yang ingin mereka lakukan (aturan-aturan sosial), hal apa yang sering mereka lakukan (kebiasaan) serta konsekuensi perilaku apa yang mereka pikirkan. Sikap yang berhubungan dengan komponen afektif mempunyai kecenderungan suka atau tidak suka sedangkan komponen kognitif berkaitan dengan keyakinan. Sikap juga memberikan serta melayani suatu hal yang bermanfaat atau suatu kebutuhan yang memuaskan. Faktor lingkungan sekitar dan kebiasaan mempengaruhi pembentukkan sikap yang dimiliki seseorang terhadap uang (Pradanti, 2014).

Banyak faktor yang menyebabkan lingkungan sebagai pembentuk sikap seseorang, diantaranya adalah faktor etnis yang membentuk suatu kebudayaan. Kebudayaan tersebut yang akan berpengaruh terhadap sikap dan perilaku yang dimiliki seseorang. Keinginan seseorang dipacu tentang hal apa yang mereka pikirkan, sehingga jika keinginan seseorang akan uang berlebihan maka mereka cenderung akan melakukan perbuatan diluar etika demi memenuhi keinginan mereka akan hal tersebut. Mengenai hubungannya dengan pendidikan sehingga pendidikan yang berkaitan dengan uang tidak saja hanya dipelajari melalui pendidikan formal saja tetapi juga dipengaruhi oleh pendidikan yang non formal didalamnya mencakup lingkungan dimana seseorang itu tinggal yang banyak sedikitnya akan mempengaruhi pola pikir serta sikap yang mereka miliki (Pradanti, 2014).

\section{Teori Harapan (Expectacy Theory)}

Teori harapan didasarkan pada motivasi dalam berperilaku yang akan menghasilkan kombinasi suatu keinginan yang diharapkan sebagai suatu hasil (Fatimah, 2017). Orangorang akan termotivasi untuk melakukan hal-hal tertentu guna mencapai tujuan apabila mereka yakin bahwa tindakan mereka akan mengarah pada pencapaian tujuan tersebut. Teori harapan menjelaskan mengenai motivasi yang dimiliki karyawan untuk mengeluarkan tingkat usaha yang tinggi dengan melakukan kinerja yang baik karena mereka berkeyakinan bahwa kinerja yang baik akan menghasilkan penilaian kinerja yang baik pula. Penilaian kinerja yang baik dapat berupa imbalan yang tinggi dari atasan atau mendapatkan sebuah penghargaan. Motivasi yang dimiliki oleh karyawan berhubungan dengan perilaku etis karyawan itu sendiri. Karyawan yang memiliki perilaku yang etis cenderung memiliki motivasi untuk menghasilkan kinerja yang baik dan memuaskan (Sipayung, 2015).

Didalam teori ini, persepsi memainkan peran inti karena persepsi menekankan pada kemampuan kognitif untuk mengantisipasi konsekuensi perilaku yang sering terjadi (Saputri, 2018). Teori harapan ini digunakan dalam memperhitungkan perilaku pada setiap keadaan yang mana terdapat dua pilihan alternatif atau lebih. Dalam penelitian ini teori harapan dapat digunakan untuk melihat hubungan love of money terhadap persepsi etis dengan cara mengidentifikasi faktor-faktor apa saja yang mempengaruhinya (Saputri, 2018).

\section{Persepsi Etis Mahasiswa Akuntansi}

Kata persepsi berasal dari kata "perception" berarti penglihatan, tanggapan, daya untuk memahami atau menanggapi sesuatu rule diawali dengan indera kemudian di transfer ke otak. Persepsi merupakan cara pandang seseorang yang melibatkan pengetahuan yang dimiliki sebelumnya dalam melihat suatu masalah atau permasalahan. Etika 
berhubungan dengan pernyataan bagaimana seseorang bertindak terhadap orang lain (Jusup, 2010).

Etis adalah nilai atau norma yamg menjadi suatu pedoman dari setiap individu. Persepsi etis adalah gabungan antara persepsi dan etika. Berdasarkan definisi persepsi dan etika, maka persepsi etis diartikan sebagai proses bagaimana sesorang menyeleksi, mengatur dan menginterpretasikan masukan-masukan informasi dan pengalaman-pengalaman yang ada dan kemudian menafsirkannya untuk menciptakan keseluruhan makna yang terkandung di dalamnya sesuai dengan prinsip kebenaran, akhlak,dan moral yang berlaku. Dapat disimpulkan bahwa persepsi etis adalah anggapan atau suatu pemikiran seseorang berdasarkan nilai moral seseorang. Dalam penelitian ini persepsi etis adalah pandangan seseorang dalam melihat kecurangan akuntansi yang terjadi (Fatimah, 2017).

\section{Pengetahuan Etika}

Pengetahuan merupakan salah satu cara untuk memahami etika. Salah satu bentuk upaya untuk membekali calon akuntan dengan etika dilakukan oleh International Federation of Accountants (IFAC) dengan mengeluarkan standar pendidikan internasional (International Education Standards/IES) untuk calon akuntan. Standar tersebut mengatur nilai-nilai yang harus diperoleh untuk memenuhi kualifikasi akuntan profesional. Nilai tersebut antara lain yaitu nilai profesional, etika dan sikap akuntan profesional. Nilainilai ini perlu diberikan dengan tujuan agar calon akuntan dapat mengambil keputusan yang etis sesuai kepentingan masyarakat luas (Sari, 2018).

\section{Love Of Money}

Uang (money) berguna untuk mempelajari perilaku manusia melalui sikap mereka. Sikap tersebut diwujudkan dalam bentuk rasa cinta terhadap uang atau love of money. Memperkenalkan konsep "the love of money" sebagai literature psikologis yang merupakan ukuran perasaan subjektif seseorang tentang uang. Love of money mengukur seberapa jauh kecintaan seseorang kepada uang nantinya akan berpengaruh pada persepsi etisnya. menyebutkan bahwa mereka yang tidak mencintai uang akan mempunyai perhatian paling rendah untuk kepuasan kebutuhan manusia, sedangkan pecinta uang mempunyai perhatian lebih tinggi terhadap kepuasan pemenuhan kebutuhan manusia (Tang, 2016).

\section{Hipotesis}

Pengaruh Pengetahuan Etika Terhadap Persepsi Etis Mahasiswa Akuntansi

Pengetahuan merupakan salah satu cara untuk memahami etika. Salah satu bentuk upaya untuk membekali calon akuntan dengan etika dilakukan oleh International Federation of Accountants (IFAC) dengan mengeluarkan standar pendidikan internasional (International Education Standards/IES) untuk calon akuntan. Standar tersebut mengatur nilai-nilai yang harus diperoleh untuk memenuhi kualifikasi akuntan profesional. Nilai tersebut antara lain yaitu nilai profesional, etika dan sikap akuntan profesional. Nilainilai ini perlu diberikan dengan tujuan agar calon akuntan dapat mengambil keputusan yang etis sesuai kepentingan masyarakat luas (Sari, 2018).

Teori sikap dan perilaku merupakan perilaku seseorang yang ditentukan oleh sesuatu yang orang lain ingin lakukan (sikap), pemikiran tentang apa yang ingin mereka lakukan (aturan-aturan sosial), hal apa yang sering mereka lakukan (kebiasaan) serta konsekuensi perilaku apa yang mereka pikirkan (Pradanti, 2014). Pengetahaun etika adalah informasi yang dimiliki dan diketahui oleh seseorang untuk memecahkan masalah berdasarkan etika yang berlaku. Mahasiswa akuntansi akan menjadi seorang calon akuntan di masa depan dan dalam profesi akuntansi akan menemui permasalahan terkait dengan 
aspek etika. Seorang akuntan harus dapat menentukan suatu tindakan itu etis atau tidak. Untuk bisa menentukan sesuatu tindakan etis atau tidak maka seseorang harus memiliki pengetahuan mengenai apa yang etis dan tidak, dan pengetahuan itu disebut sebagai pengetahuan etika.

Berdasarkan teori sikap dan perilaku mahasiswa yang memiliki pengetahuan yang luas mengenai prinsip etika profesi akan dapat bersikap lebih bijaksana dan mampu memberikan tanggapan berupa ketidaksetujuan mengenai skandal etis yang menimpa profesi akuntan dibanding mahasiswa yang memiliki pengetahuan lebih sedikit. Dengan demikian diharapkan seseorang yang memiliki pengetahuan etika yang tinggi dan luas maka dia akan mampu membedakan mana sesuatu itu etis dan mana yang tidak etis. Pengetahuan etika berpengaruh positif terhadap Persepsi etis mahasiswa akuntansi UNY dan mahasiswa akuntansi syariah UIN SUKA. (Diana, 2017). Semakin tinggi tingkat pengetahuan, maka semakin tinggi persepsi etis yang dimiliki. Keberadaan pengetahuan sebagai wawasan akan menjadi bekal bagi setiap individu dalam menyikapi perubahan yang terjadi dilingkungannya. Pengetahuan memberikan informasi yang bermanfaat untuk mencari solusi atas berbagai permasalahan yang terjadi. Pengetahuan memberikan acuan dalam bertindak dimasa sekarang dan masa yang akan datang dengan mempelajari peristiwa yang terjadi dimasa lampau. Pengetahuan mengenai etika yang dimiliki seseorang akan memberikan informasi berkaitan dengan suatu etika yang berlaku (Lili, 2018).

Pengetahuan tentunya tidak hanya bisa didapat di media formal seperti sekolah tetapi melalui pengalaman, pengetahuan itu juga bisa didapat. Seseorang yang memiliki pengetahuan etika akan bersikap atau berperilaku sesuai etika yang diketahuinya. Semakin banyak atau luas pengetahuan etika yang dimiliki oleh seorang mahasiswa akuntansi, maka semakin tinggi persepsi etis mahasiswa akuntansi atas perilaku tidak etis akuntan atau kemungkinan untuk melakukan perilaku tidak etis semakin rendah. Pengetahuan berpengaruh positif terhadap persepsi etis mahasiswa (Lili, 2018). Berdasarkan uraian penjelasan diatas maka rumusan hipotesis penelitian adalah sebagai berikut:

\section{H1: Pengetahuan Etika Berpengaruh Positif Terhadap Persepsi Etis Mahasiswa Akuntansi}

\section{Pengaruh Love of Money Terhadap Persepsi Etis Mahasiswa Akuntansi}

Uang adalah aspek yang sangat penting dalam kehidupan sehari-hari. Dalam proses sosialisasi uang dipelajari melalui tahapan proses sosialisasi dari masa anak-anak sampai dewasa. Dalam dunia bisnis, manajer menggunakan uang untuk memotivasi karyawannya (Fatimah, (2017). Karena pentingnya uang dan interpretasi yang berbeda maka konsep "love of money" untuk mengukur perasaan subyektif seseorang terhadap uang (Sipayung, 2015). Persepsi seseorang dipengaruhi oleh etika yang dimilikinya berpendapat bahwa kecintaan terhadap uang berdampak secara signifikan terhadap perilaku yang tidak etis. Love of money dan persepsi etis memiliki hubungan yang negatif. Semakin tinggi tingkat love of money yang dimiliki seseorang, maka akan semakin rendah persepsi etis yang dimilikinya, begitu pula sebaliknya. Semakin tinggi etika yang dimiliki maka tingkat kecintaan terhadap uang yang ia miliki cenderung semakin rendah (Pradanti, 2014). Love of money berpengaruh signifikan terhadap persepsi etis mahasiswa akuntansi (Pradanti, 2014). Berdasarkan uraian penjelasan diatas maka rumusan hipotesis penelitian adalah sebagai berikut:

H2: Love of Money Berpengaruh Negatif Terhadap Persepsi Etis Mahasiswa Akuntansi Syariah 


\section{Pengaruh Pengetahuan Etika Terhadap Love of Money}

Pengetahuan mengenai perilaku benar-salah atau baik-buruk diperoleh melalui pengalaman, pembelajaran dan pendidikan. Melalui pendidikan etika di bangku perkuliahan mahasiswa akan mempunyai karakteristik untuk menjunjung tinggi nilainilai etika sebelum memasuki dunia kerja Sari (2018).

Pengaruh pengetahuan etika terhadap love of money dapat diketahui bahwa love of money berpengaruh negatif antara tingkat pengetahuan dikarenakan tidak signifikan. Hal tersebut disebabkan karena tingkat pengetahuan seseorang terhadap suatu kasus tidak bisa berubah walaupun dengan adanya kecintaan terhadap uang (love of money). Hal ini dimungkinkan sampel yang digunakan dalam penelitian ini merupakan mahasiswa yang kebutuhan akan uang masih sangat rendah dan mereka berada dalam lingkungan akademis yang agamis atau religius. Sehingga love of money tidak mempengaruhi mereka dalam memberikan persepsi atas adanya kasus yang terjadi (Rahayuningsih, 2016). Berdasarkan uraian penjelasan diatas maka rumusan hipotesis penelitian adalah sebagai berikut:

H3: Pengetahuan Etika Berpengaruh Positif Terhadap Love of Money

Pengaruh Pengetahuan Etika Terhadap Persepsi Etis Mahasiswa Akuntansi Melalui Love of Money Sebagai Variabel Intervening

Pengetahuan merupakan salah satu cara untuk memahami etika. Etika merupakan prinsip moral dan nilai yang diketahui sebagai sesuatu yang baik dan benar. Etika adalah sifat dasar yang harus dimiliki oleh seseorang atau sebuah organisasi sebagai pedoman berperilaku dalam kehidupan bermasyarakat. Pengetahuan merupakan salah satu cara untuk memahami etika. Seseorang yang memiliki perilaku etis berarti telah mengetahui hal baik, menyukai hal baik, dan melakukan hal baik.
Seseorang yang telah mendapat pendidikan etika diasumsikan telah mengetahui hal baik, sehingga memiliki perilaku yang lebih etis dibandingkan orang yang belum mendapatkan pendidikan etika (Sari, 2018).

Teori sikap dan perilaku merupakan perilaku seseorang yang ditentukan oleh sesuatu yang orang lain ingin lakukan (sikap), pemikiran tentang apa yang ingin mereka lakukan (aturan-aturan sosial), hal apa yang sering mereka lakukan (kebiasaan) serta konsekuensi perilaku apa yang mereka pikirkan (Pradanti, 2014). Persepsi seseorang dipengaruhi oleh etika yang dimilikinya berpendapat bahwa kecintaan terhadap uang berdampak secara signifikan terhadap perilaku yang tidak etis. Love of money dan persepsi etis memiliki hubungan yang negatif. Semakin tinggi tingkat love of money yang dimiliki seseorang, maka akan semakin rendah persepsi etis yang dimilikinya, begitu pula sebaliknya. Semakin tinggi etika yang dimiliki maka tingkat kecintaan terhadap uang yang ia miliki cenderung semakin rendah (Pradanti, 2014).

Uang adalah aspek yang sangat penting dalam kehidupan sehari-hari. Dalam proses sosialisasi uang dipelajari melalui tahapan proses sosialisasi dari masa anak-anak sampai dewasa. Dalam dunia bisnis, manajer menggunakan uang untuk memotivasi karyawannya (Fatimah, (2017). Karena pentingnya uang dan interpretasi yang berbeda maka konsep "love of money" untuk mengukur perasaan subyektif seseorang terhadap uang (Sipayung, 2015).

Pengaruh pengetahuan etika terhadap love of money dapat diketahui bahwa love of money berpengaruh negatif antara tingkat pengetahuan dikarenakan tidak signifikan. Dari beberapa pernyataan diatas dapat disimpulkan bahwa pengetahuan etika berpengaruh negatif terhadap persepsi etis mahasiswa akuntansi melaui love of money sebagai variabel intervening. Hal tersebut disebabkan karena tingkat pengetahuan seseorang terhadap suatu kasus tidak bisa berubah walaupun 
dengan adanya kecintaan terhadap uang (love of money) (Rahayuningsih, 2016). Berdasarkan uraian penjelasan diatas maka rumusan hipotesis penelitian adalah sebagai berikut:

H4: Pengetahuan Etika Berpengaruh Negatif Terhadap Persepsi Etis Mahasiswa Akuntansi Melalui Love of Money Sebagai Variabel Intervening.

\section{Kerangka Pikir Penelitian}

Berdasarkan uraian hipotesis diatas, dapat digambarkan kerangka pikir penelitian sebagai berikut:

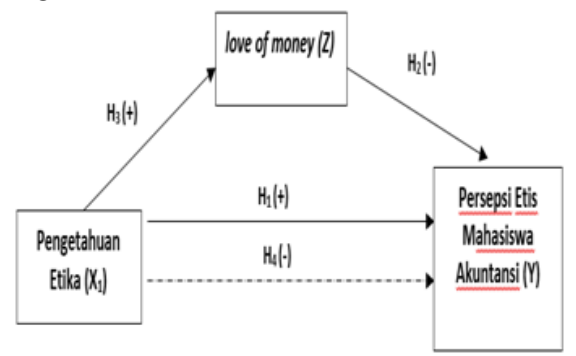

\section{Gambar 1 \\ Kerangka Pikir}

\section{Metode Penelitian}

Sifat penelitian ini adalah penelitian kuantitatif. Menurut Diana (2017) disebut penelitian kuantitatif karena data penelitian berupa angka-angka dan analisis menggunakan statistik. Penelitian ini menggunakan data primer yang diperoleh melalui metode survei dengan pembagian kuesioner kepada responden.

Populasi adalah kelompok elemen yang lengkap, yang biasanya berupa orang, objek, transaksi atau kejadian dimana kita ditarik untuk mempelajarinya atau menjadi objek penelitian (Kuncoro, 2013). Populasi dalam penelitian ini adalah Mahasiswa Program S1 Akuntansi di lima Perguruan Tinggi di Daaerah Istimewa Yogyakarta yang meliputi UGM (Universitas Gadjah Mada), UNY (Universitas Negeri Yogyakarta), USD (Universitas Sanata
Dharma), UII (Universitas Islam Indonesia) dan UST (Universitas Sarjanawiyata Tamansiswa).

Sampel adalah bagian dari populasi yang diharapkan dapat mewakili populasi penelitian (Kuncoro, 2013). Teknik pengambilan sampel yang digunakan adalah convenience sampling yaitu subyek yang paling mudah ditemui akan dijadikan responden dalam penelitian. Jumlah sampel pada penelitian ini sebanyak 90 orang. Pengambilan sampel atas responden dilakukan dengan sampel probabilitas melalui metode snowball sampling dimana kuesioner dalam bentuk angket dan google form diserahkan kepada orang lain untuk kembali disebarkan kepada responden agar memperoleh data lebih banyak.

Dalam metode analisis data, penelitian menggunakan analisis linear regresi berganda dan path analysis untuk menguji variabel intervening. Langkah-langkah analisis sebagai berikut:

1. Uji Kualitas Data
a. Uji Validitas
b. Uji

\section{Reliabilitas}

2. Statistik Deskriptif

3. Uji Asumsi Klasik
a. Uji Normalitas Data
b. Uji Multikolinearitas
c. Uji Heteroskedastisitas

4. Teknik Analisis Data
a. Analisis Jalur (Path analysis)
b. Uji Parsial (Uji t)
c. Uji F
d. Analisis Koefisien Determinasi $\left(\mathrm{R}^{2}\right)$

\section{Hasil Penelitian dan Pembahasan}

\section{Hasil Uji Asumsi Klasik Hasil Uji Normalitas}

Uji normalitas data bertujuan untuk menguji apakah dalam model regresi, variabel penggangu atau residual memiliki distribusi normal. Pengujian normalitas data 
dengan 2 persamaan menggunakan uji statistik non parametrik KolmogorovSmirnov (K-S) dengan bantuan SPSS versi 18.0. tabel 1 dibawah ini menyajikan mengenai hasil pengujian normalitas data:

Tabel 1

One-Sample Kolmogorov-Smirnov Test

\begin{tabular}{|c|c|c|}
\hline & & $\begin{array}{c}\begin{array}{c}\text { Unstandardized } \\
\text { Residual }\end{array} \\
\end{array}$ \\
\hline $\begin{array}{l}\text { N } \\
\text { Normal } \\
\text { Parametersab } \\
\text { Most Extreme } \\
\text { Differences }\end{array}$ & $\begin{array}{l}\text { Mean } \\
\text { Std. Deviation } \\
\text { Absolute } \\
\text { Positive } \\
\text { Negative }\end{array}$ & $\begin{array}{r}90 \\
, 0000000 \\
3,13848642 \\
.064 \\
.064 \\
-038\end{array}$ \\
\hline \multicolumn{2}{|c|}{$\begin{array}{l}\text { Kolmogorov-Smimov Z } \\
\text { Asymp. Siz. (2-tailed) }\end{array}$} & $\begin{array}{r}.611 \\
.849 \\
\end{array}$ \\
\hline
\end{tabular}

Dari hasil uji normalitas menggunakan metode Kolmogorov Sminov didapatkan hasil signifikansi dari uji normalitas sebesar 0,849 dimana hasil tersebut lebih besar dari taraf signifikansi 0,05. Sehingga disimpulkan bahwa uji tes normalitas pada penelitian ini adalah terdistribusi normal.

\section{Uji Multikolinearitas}

Uji multikolinearitas dilakukan untuk mengetahui besarnya interkorelasi antar variabel bebas dalam penelitian ini. Jika terjadi korelasi, maka dinamakan terdapat masalah multikolinieritas. Untuk mendeteksi ada tidaknya multikolinearitas dapat dilihat pada nilai Tolerance dan VIF. Apabila nilai tolerance diatas 0,1 dan nilai VIF dibawah 10 maka tidak terjadi multikolinearitas (Imam, 2011). Hasil uji multikolinearitas dapat dilihat pada tabel berikut ini.

\section{Tabel 2}

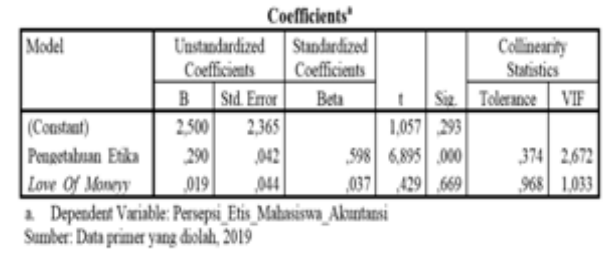

Dapat dilihat pada tabel 2 Variabel pengetahuan etika memiliki nilai 286 tolerance sebesar 0,374 dan nilai VIF sebesar 2,672. Variabel Love_Of_Money memiliki nilai tolerance sebesar 0,968 dan nilai VIF sebesar 1,033.Sehingga disimpulkan bahwa uji tes multikolinearitas pada penelitian ini pervariabel nilai tolerance diatas 0,1 dan nilai VIF dibawah 10 maka artinya tidak terjadi multikolinearitas.

\section{Uji Heteroskedastisitas}

Berdasarkan tabel 3 berikut ini hasil uji glesjer dapat dairtikan bahwa tidak terdapat gejala heteroskedastisitas. Hal ini didukung dengan nilai signifikansi dari masingmasing variabel yang berada diatas 0,05 .

Tabel 3

\begin{tabular}{|c|c|c|c|c|c|}
\hline \multirow[t]{2}{*}{ Model } & \multicolumn{2}{|c|}{$\begin{array}{l}\text { Unstandardized } \\
\text { Coefficients }\end{array}$} & \multirow{2}{*}{\begin{tabular}{|c|}
$\begin{array}{c}\text { Standardized } \\
\text { Coefficients }\end{array}$ \\
Beta \\
\end{tabular}} & \multirow[b]{2}{*}{$t$} & \multirow[b]{2}{*}{ Siz. } \\
\hline & B & Std. Error & & & \\
\hline 1 (Constant) & 2,500 & 2,365 & & 1,057 & 293 \\
\hline Pengetahuan Etika & 290 & .042 & 598 & 6,895 & .000 \\
\hline Love of Moneyy & 019 &, 044 & .037 & .429 & .669 \\
\hline
\end{tabular}

\section{Teknik Analisis Data}

\section{Uji Simultan (F)}

Uji statistik $\mathrm{F}$ ini digunakan untuk menguji variabel bebas secara bersama-sama mempengaruhi variabel terikat. Berdasarkan tabel 4 tersebut menunjukkan hasil uji model fit menyatakan bahwa variabel pengetahuan etika dan love of money berpengaruh dengan angka signifikansinya sebesar 0,000 . Apabila $F_{\text {hitung hasil output dari program SPSS }}$ sebesar 25,190. Apabila nillai $F_{\text {hitung }}$ lebih besar dari $\mathrm{F}_{\text {tabel }}$, maka model dinyatakan fit. Nilai $F_{\text {hitung }} 25,190$ lebih besar dari $F_{\text {tabel }}$ 3,10 sehingga model dikatakan fit atau sesuai. 
Tabel 4

\begin{tabular}{l} 
Hasil Uji Simultan (F) \\
Substruktur 1 \\
\begin{tabular}{|l|r|r|r|r|r|}
\hline Model & Sum of Squares & Df & Mean Square & F & Sig. \\
\hline I Repression & 507,664 & 2 & 253,832 & 25,190 &, $000^{\circ}$ \\
Residual & 876,659 & 87 & 10,077 & & \\
Total & 1384,322 & 89 & & & \\
\hline
\end{tabular} \\
a. Predictors: (Constant), Love Of Moecyy, Pengetaluan Etika \\
b. Dependent Variable: Persepsi_Etis_Mahasiswa_Alumtansi \\
\hline
\end{tabular}

Pada tabel 5 hasil uji model fit menyatakan bahwa variabel pengetahuan etika dan persepsi etis mahasiswa akuntansi berpengaruh dengan angka signifikansinya sebesar 0,002 . Apabila $F_{\text {hitung hasil output }}$ dari program SPSS sebesar 5,436. Apabila nillai $F_{\text {hitung }}$ lebih besar dari $F_{\text {tabel }}$, maka model dinyatakan fit. Nilai $F_{\text {hitung }} 5,436$ lebih besar dari $F_{\text {tabel }} 3,10$ sehingga model dikatakan fit atau sesuai.

\section{Tabel 5}

Hasil Uji Simultan (F) Substruktur 2

\begin{tabular}{|c|c|c|c|c|c|}
\hline Model & Sum of Squares & df & Mean Souare & $\mathrm{F}$ & Sig \\
\hline 1 Regressice & 180,662 & 2 & 90,331 & 5,436 &, $002^{\circ}$ \\
\hline Residual & 5177,294 & 87 & 59,509 & & \\
\hline Total & 5357,956 & 89 & & & \\
\hline
\end{tabular}

\section{Uji Parsial (Uji t)}

Berdasarkan tabel 6 berikut merupakan hasil uji persial sub struktur 2 yang menunjukkan pengaruh variabel pengetahuan etika $\left(\mathrm{X}_{1}\right)$ dan love of money (Z) terhadap persepsi etis mahasiswa akuntansi (Y). Berdasarkan tabel tersebut, dapat diketahui nilai signifikansi pengetahuan etika sebesar $0,000<0,05$ dengan nilai thitung lebih besar dari ttabel yaitu $=6,895>1,663$. Dengan demikian hipotesis yang menyatakan pengetahuan etika berpengaruh positif terhadap persepsi etis mahasiswa akuntansi terdukung.

Nilai signifikansi love of money sebesar 0,669>0,05 dengan nilai thitung lebih besar dari ttabel yaitu $=1,187>$ 1,663. Dengan demikian hipotesis yang menyatakan love of money berpengaruh negatif terhadap persepsi etis mahasiswa akuntansi tidak terdukung.

\section{Tabel 6}

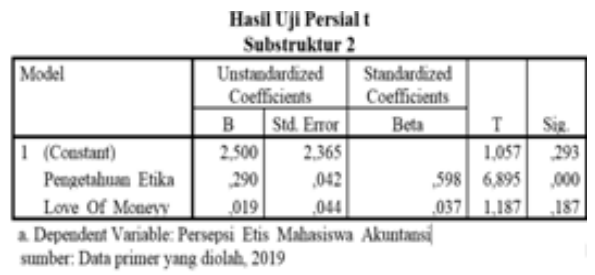

Berdasarkan tabel 7 berikut merupakan hasil uji persial substruktur 1 yang menunjukkan pengaruh variabel pengetahuan etika $\left(\mathrm{X}_{1}\right)$ dan persepsi etis mahasiswa akuntansi (Y) terhadap love of money (Z). Nilai signifikansi pengetahuan etika sebesar $0,434>0,05$ dengan nilai thitung lebih kecil dari ttabel yaitu $=-0,786$ $<1,663$. Dengan demikian hipotesis yang menyatakan pengetahuan etika berpengaruh negatif terhadap love of money tidak terdukung.

Nilai signifikansi love of money sebesar 0,852>0,05 dengan nilai thitung lebih besar dari ttabel yaitu $=0,187<$ 1,663. Dengan demikian hipotesis yang menyatakan love of money berpengaruh negatif terhadap persepsi etis mahasiswa akuntansi tidak terdukung.

\section{Tabel 7}

Hasil Uji Persial t

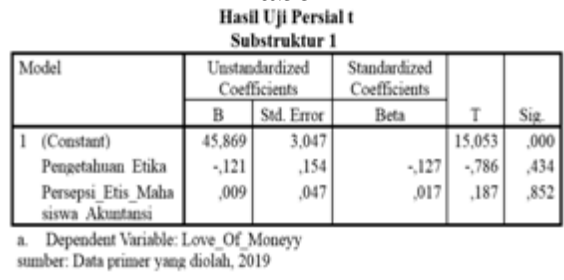




\section{Analisis Jalur (Path analysis)}

Gambar 1 berikut ini menunjukkan masingmasing nilai beta. Nilai beta pengetahuan etika terhadap persepsi etis mahasiswa akuntansi adalah 0,598. Nilai beta love of money terhadap terhadap persepsi etis mahasiswa akuntansi memiliki nilai beta sebesar 0,037. Berdasarkan tabel diatas diketahui nilai $\mathrm{e}_{1}=\sqrt{ }(1-\mathrm{R}$ Square, sehingga $\mathrm{e}_{1}=\sqrt{(1-0,606)}=0,628$.

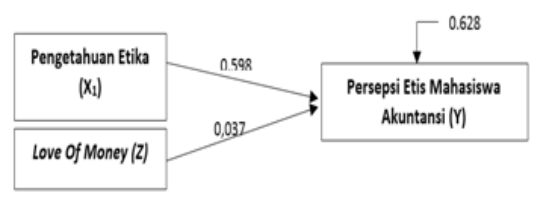

\section{Gambar 2 \\ Diagram Jalur Model 1}

Berdasarkan tabel diatas diketahui nilai $\mathrm{e}_{2}$ $=\sqrt{ }\left(1-\mathrm{R}\right.$ Square, sehingga $\mathrm{e}_{2}=\sqrt{(1-0,184)}$ $=0,903$. Gambar 2 berikut ini menunjukkan masing-masing nilai beta. Nilai beta pengetahuan etika terhadap persepsi etis mahasiswa akuntansi adalah 0,598. Nilai beta love of money terhadap persepsi etis mahasiswa akuntansi sebesar 0,009. Nilai beta pengetahuan etika terhadap love of money sebesar -0,121. Pengaruh tidak langsung dapat diketahui dengan cara mengalikan nilai beta variabel independen terhadap variabel intervening dengan nilai beta variabel intervening terhadap variabel dependen. Pengaruh langsung pengetahuan etika terhadap persepsi etis mahasiswa akuntansi dapat dilihat dari nilai beta sebesar 0,598, sedangkan pengaruh tidak langsung pengetahuan etika terhadap persepsi etis mahasiswa akuntansi melalui love of money adalah perkalian antara nilai beta variabel independen terhadap variabel intervening dengan nilai beta variabel intervening terhadap variabel dependen, yaitu $-0,121 \times 0,009=-0,001$. Pengaruh total yang diberikan variabel $\mathrm{X}_{1}$ melalui $\mathrm{Z}$ terhadap $\mathrm{Y}$ adalah $0,598+(-0,001)=$ -
0,597. Berdasarkan perhitungan diatas dapat diketahui bahwa besarnya pengaruh langsung adalah 0,598 sedangkan besarnya pengaruh tidak langsung adalah -0,597, sehingga dapat disimpulkan bahwa pengaruh langsung lebih besar dari pada pengaruh tidak langsung. Artinya, pengetahuan etika tidak berpengaruh terhadap persepsi etis mahasiswa akuntansi melalui love of money.

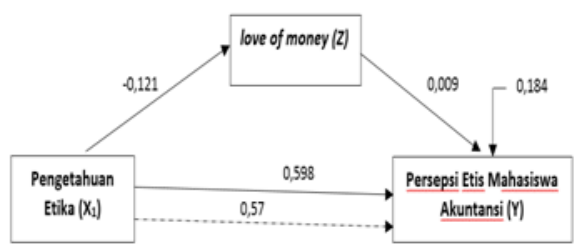

Gambar 3 Diagram Jalur Model 2

\section{Analisis Koefisien Determinasi $\left(\mathbf{R}^{\mathbf{2}}\right)$}

Berdasarkan tabel 8 tersebut besarnya angka $\mathrm{R}$ square $\left(\mathrm{R}^{2}\right)$ digunakan untuk melihat pengaruh variabel pengetahuan etika dan love of money terhadap persepsi etis mahasiswa akuntansi memiliki kontribusi sebesar 0,367 atau 36,7 \% sementara sisanya sebesar 0,606 atau $60,6 \%$ dipengaruhi oleh faktor lain seperti gender, religius, ethnic background, dan prestasi belajar.

Berdasarkan tabel 9 tersebut besarnya angka $\mathrm{R}$ square $\left(\mathrm{R}^{2}\right)$ digunakan untuk melihat pengaruh variabel pengetahuan etika dan persepsi etis mahasiswa akuntansi terhadap love of money memiliki kontribusi sebesar 0,034 atau $34,0 \%$ sementara sisanya sebesar 0,184 atau $18,4 \%$ dipengaruhi oleh faktor lain seperti gender, religius, ethnic background, dan prestasi belajar. 

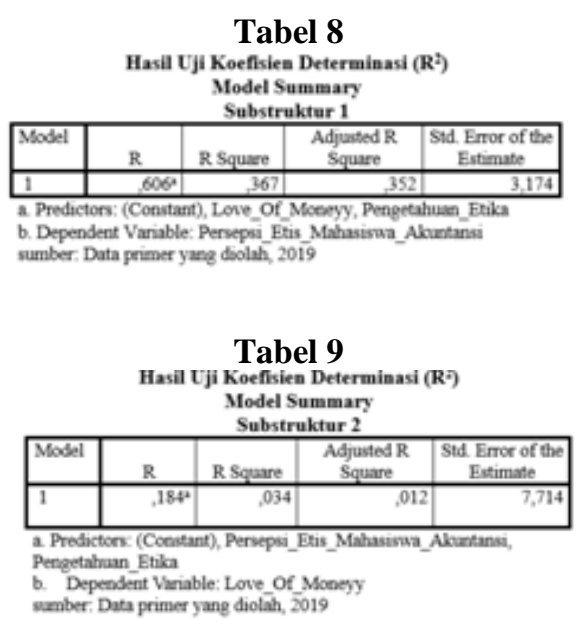

\section{Diskusi}

Pengaruh Pengetahuan Etika terhadap Persepsi Etis Mahasiswa Akuntansi

Hipotesis pertama yang diajukan dalam penelitian ini adalah pengetahuan etika berpengaruh positif terhadap persepsi etis mahasiswa akuntansi. Hasil uji hipotesis pertama menyimpulkan bahwa pengetahuan etika berpengaruh terhadap persepsi etis mahasiswa akuntansi. Hal ini dibuktikan dengan nilai thitung lebih besar dari ttabel yaitu $=6,895>1,663$ dengan nilai signifikansinya sebesar 0,000 lebih kecil dari 0,05 dan nilai unstandardized coefficients B sebesar 0,290. Berdasarkan hasil data tersebut, maka pengetahuan etika berpengaruh terhadap persepsi etis mahasiswa akuntansi. Dengan demikian $\mathrm{H}_{1}$ diterima.

Informasi yang dimiliki oleh seseorang akan mempengaruhi pengetahuan yang dimiliki. Pengetahuan dapat diperoleh melalui proses pembelajaran baik melalui pendidikan formal maupun non formal. Pengetahuan akan membantu dalam memudahkan sebuah masalah dapat diselesaikan, tindakan apa yang seharusnya dilakukan dan solusi terbaik apa yang akan diberikan. Pengetahuan etika yang dimiliki seseorang akan menjadi informasi terkait dengan etika atau aturan yang berlaku. Oleh karena itu seseorang yang mempunyai pengetahuan etika tinggi akan bersikap sesuai dengan etika yang berlaku. Seseorang yang mempunyai etika akan dapat bereaksi atas tindakan yang tidak etis. Hal tersebut sesuai dengan teori tahapan perkembangan moral, dimana pada usia di atas 13 tahun, seseorang akan cenderung berorientasi pada etika. Semakin luas pengetahuan etika yang dimiliki oleh mahasiswa akuntansi maka persepsi etis mahasiswa akuntansi semakin tinggi (Diana, 2017).

Hasil penelitian ini sejalan dengan penilitian Diana (2017) yang menyatakan bahwa pengetahuan etika berpengaruh terhadap persepsi etis mahasiswa akuntansi.

\section{Pengaruh Love Of Money Terhadap Persepsi Etis Mahasiswa Akuntansi}

Hipotesis ketujuh yang diajukan dalam penelitian ini adalah love of money berpengaruh negatif terhadap persepsi etis mahasiswa akuntansi. Hasil uji hipotesis ketujuh menyimpulkan bahwa love of money tidak berpengaruh terhadap persepsi etis mahasiswa akuntansi. Hal ini dibuktikan dengan nilai thitung lebih besar dari ttabel yaitu $=1,187>1,663$. Memiliki angka signifikansinya sebesar 0,187 lebih besar dari 0,05 dan nilai unstandardized coefficients B sebesar 0,019. Berdasarkan hasil data tersebut, maka love of money tidak berpengaruh terhadap persepsi etis mahasiswa akuntansi. Dengan demikian $\mathrm{H}_{2}$ ditolak.

Seorang mahasiswa yang lebih mementingkan uang memiliki tingkat persepsi etis yang lebih rendah dibandingan dengan mahasiswa yang tidak terlalu mementingkan uang yang lebih tinggi. Hal ini disebabkan karena apabila seseorang memiliki kecintaan uang yang tinggi, maka ia akan berusaha untuk melakukan segala cara agar kebutuhannya terpenuhi namun tidak sesuai dengan etika. Hubungan antara perilaku cinta uang dan persepsi etis telah diteliti lebih lanjut di beberapa negara. Fatimah (2017) menguji hubungan Love of Money apabila dikaitkan dengan persepsi 
etis menghasilkan hubungan yang negatif. Hal ini didukung oleh Fatimah (2017) yang memiliki pendapat bahwa etika uang seseorang memiliki dampak yang signifikan dan langsung pada perilaku yang tidak etis.

Hasil penelitian ini tidak sama dengan penelitian Saputri (2018) yang menyatakan bahwa love of money tidak berpengaruh terhadap persepsi etis mahasiswa akuntansi.

\section{Pengaruh Pengetahuan Etika Terhadap Love Of Money}

Hipotesis keempat yang diajukan dalam penelitian ini adalah pengetahuan etika berpengaruh negatif terhadap love of money. Hasil uji hipotesis keempat menyimpulkan bahwa pengetahuan etika tidak berpengaruh terhadap love of money. Hal ini dibuktikan dengan nilai thitung lebih kecil dari ttabel yaitu $=-0,786<1,663$. Memiliki angka signifikansinya sebesar 0,434 lebih besar dari 0,05 dan nilai unstandardized coefficients B sebesar 1,121. berdasarkan hasil data tersebut, maka pengetahuan etika tidak berpengaruh terhadap love of money. Dengan demikian $\mathrm{H}_{3}$ ditolak.

Tingkat pengetahuan seseorang terhadap suatu kasus tidak bisa berubah walaupun dengan adanya kecintaan terhadap uang (love of money). Hal ini dimungkinkan sampel yang digunakan dalam penelitian ini merupakan mahasiswa yang kebutuhan akan uang masih sangat rendah dan mereka berada dalam lingkungan akademis yang agamis atau religius. Sehingga love of money tidak mempengaruhi mereka dalam memberikan persepsi atas adanya kasus yang terjadi (Rahayuningsih, 2016).

Hasil penelitian ini sama dengan penilitian Rahayuningsih (2016) yang menyatakan bahwa pengetahuan etika tidak berpengaruh terhadap love of money.

\section{Pengaruh Pengetahuan Etika Terhadap Persepsi Etis Mahasiswa Akuntansi Melalui Love of Money Sebagai Variabel Intervening}

Hipotesis kedelapan dalam penelitian ini adalah pengetahuan etika berpengaruh negatif terhadap persepsi etis mahasiswa akuntansi melalui love of money. Hasil uji hipotesis menunjukkan besarnya pengaruh langsung pengetahuan etika terhadap persepsi etis mahasiswa akuntansi adalah 0,598, sedangkan pengaruh tidak langsungnya adalah sebesar $-0,597$. Hal ini menjelaskan bahwa pengaruh tidak langsung lebih kecil dari pada pengaruh langsung, sehingga dapat disimpulkan bahwa pengetahuan etka tidak berpengaruh terhadap persepsi etis mahasiswa akuntansi melalui love of money. Dengan demikian $\mathrm{H}_{4}$ ditolak.

Hasil penelitian ini menunjukkan bahwa pengetahuan etika melalui love of money terhadap persepsi etis mahasiswa akuntansi. Hal ini disebabkan karena tingkat pengetahuan seseorang terhadap suatu kasus tidak bisa berubah walaupun adanya kecintaan terhadap uang (love of money). Hal ini dimungkinkan sampel yang digunakan dalam penelitina ini merupakan mahasiswa yang kebutuhan akan uang masih sangat rendah dan mereka berada dalam lingkungan akademis (Rahayuningsih, 2016).

Hasil penelitian ini sejalan dengan penilitian Rahayuningsih (2016) yang menyatakan bahwa pengetahuan etika tidak berpengaruh terhadap persepsi etis mahasiswa akuntansi melalui love of money. 


\section{Simpulan dan Saran}

\section{Simpulan}

Berdasarkan analisis mengenai pengetahuan etika, pengalaman magang dan terhadap persepsi etis mahasiswa akuntansi dengan Love of Money sebagai variabel intervening maka dapat diambil kesimpulan sebagai berikut:

1. Pengetahuan etika berpengaruh positif terhadap persepsi etis mahasiswa akuntansi.

2. Pengetahuan etika berpengaruh negatif terhadap love of money.

3. Love of money berpengaruh negatif terhadap persepsi etis mahasiswa akuntansi.

4. Pengetahuan etika berpengaruh negatif terhadap persepsi etis mahasiswa akuntansi melalui love of money.

\section{Saran}

Dengan mempertimbangkan hasil analisis, kesimpulan, dan keterbatasan yang telah dikemukakan diatas, maka peneliti memberikan saran untuk penelitian berikutnya yaitu:

1. Diharapkan mahasiswa memiliki kemampuan untuk mengontrol kecintaannya terhadap uang sehingga mahasiswa memiliki persepsi etis yang baik, seperti :

a. Mahasiswa mampu mendahulukan kebutuhan dibandingkan kepentingannya.

b. Mahasiswa mampu menghargai nilai mata uang supaya mereka tidak terlalu mementingkan love of money.

c. Dapat bersikap jujur dalam segala pekerjaan.

2. Diharapkan nantinya sarjana-sarjana muda akuntansi yang sudah memasuki dunia kerja nantinya tidak hanya profesional dalam menjalankan pekerjaannya namun juga memiliki persepsi etis yang baik sebagai seorang akuntan.
3. Sebaiknya menambah obyek penelitian yang ada karena penelitian ini hanya melibatkan lima universitas saja.

4. Diharapkan menambah variabelvariabel independen selain variabelvariabel yang sudah ada di penelitian ini seperti pengalaman kerja, gender, usia, tingkat pendidikan, latar belakang etnis, dll

\section{Daftar Pustaka}

AJI, T. P. (2018). Pengaruh Muatan Etika Dalam Pendidikan Akuntansi, Pengetahuan Tentang Profesi Akuntan Dan Pengetahuan Tentang Skandal Keuangan Terhadap Persepsi Mahasiswa Akuntansi Syariah Mengenai Tindakan Tidak Etis Auditor. Ekonomi Dan Bisnis, 10(2), 1-15.

Al, H. J. (2010). Pengauditan. Pengauditan, 2010 (Yogyakarta), Sekolah Tinggi Ilmu Ekonomi YKPN.

Aprianti, V. (2016). Pengaruh Usia, Gender, Status Sosial Ekonomi, Dan Pengalaman Kerja Terhadap Persepsi Etis Mahasiswa Akuntansi Dengan Love Of Money Sebagai Variabel Intervening. Feb, 2016(November), 77.

Arfan, I. L. (2011). Akuntansi Keprilakuan, cetakan kedua. Jakarta: Selemba Empat.

Arifin, H. S. (2017). Analisis Faktor yang Mempengaruhi Persepsi Mahasiswa terhadap Keberadaan Perda Syariah di Kota Serang. Jurnal Penelitian Komunikasi Dan Opini Publik, 21(1), 88-101.

Charismawati, C. D., \& Yuyetta, E. N. (2011). Analisis Hubungan Antara Persepsi Etika Mahasiswa Akuntansi.http://eprints.undip.ac.id/ 29310/1/Jurnal_Celvia_Dhian_C.pdf

Diana, A. R. (2017). Pengaruh 
Pengetahuan Etika, Religiusitas Dan Love Of Money Terhadap Persepsi Etis Mahasiswa Akuntansi. $A B A$ Journal, 102(4), 24-25. https://doi.org/10.1002/ejsp.2570

Ernawati, N., \& Kuncoro, A. (2016). Determinan Persepsi Etika Mahasiswa Akuntansi Dengan Love Of Money Sebagai Variabel Intervening (Studi Kasus Mahasiswa Akuntansi Universitas Muria Kudus). Jurnal Riset Akuntansi Terpadu, 9(1). https://doi.org/10.35448/jrat.v9i1.42 79

Fatimah, N. (2017). Analisis pengaruh gender dan status ekonomi terhadap persepsi etis mahasiswa akuntansi syariah. $1-85$.

Imam, G. (2011). Aplikasi Analisis Multivariate Dengan Program SPSS". Semarang: Badan Penerbit Universitas Diponegoro. 7.

Jonathan, S. (2012). Metode Riset Skripsi Pendekatan Kuantitatif Menggunakan Prosedur SPSS (Edisi Pertama). Jakarta: PT Elex Media Komputindo. 7.

Kumala, M. R. (2016). Determinan Persepsi Etika Mahasiswa Akuntansi Dengan Love Of Money Sebagai Variabel Intervening. Ekonomi Dan Bisnis, $\quad$ 53(9), 15. https://doi.org/10.1017/CBO978110 7415324.004

Kuncoro, M. (2013). Mudah dan menganalisis indikator ekonomi. Yogyakarta: UPP STIM YKPN. Mudah Dan Menganalisis Indikator Ekonomi., 2013.

Kusnaeni, Y. (2015). Pengaruh Persepsi Tentang Kerja Praktek Lapangan, Informasi Dunia Kerja Dan Motivasi Memasuki Dunia Kerja Terhadap Kesiapan Kerja Siswa SMK Bhakti Persada Kendal. Skripsi.

Lili Cahyani, N. W. S., \& Ramantha, I. W. (2018). Pengaruh Pengetahuan, Sensitivitas Etis, Idealisme pada
Persepsi Etis Mahasiswa Akuntansi Atas Perilaku Etis Akuntan. EJurnal Akuntansi, 24, 1387. https://doi.org/10.24843/EJA.2018.v 24.i02.p21

Novitasari, D. (2013). Pengaruh Kecerdasan Emosional, Persepsi Tekanan Etis, Dan Muatan Etika Dalam Pengajaran Akuntansi Terhadap Persepsi Etis Mahasiswa Akuntansi. Journal of Chemical Information and Modeling, 2013(9), 113. https://doi.org/10.1017/CBO978110 7415324.004

Pemayun, A. W., \& Budiasih, I. G. A. N. (2018). Pengaruh Religiusitas, Status Sosial Ekonomi Dan Love of Money Pada Persepsi Etis Mahasiswa Akuntansi. E-Jurnal Akuntansi, 23, 1600.

https://doi.org/10.24843/eja.2018.v2 3.i02.p30

Pradanti, N. R., \& Prastiwi, A. (2014). Etis Mahasiswa Akuntansi. 3(2010), 111.

Purnamaningsih, N., \& Ariyanto, D. (2016). Pengaruh Gender, Usia, Tingkat Pendidikan, Dan Status Sosial Ekonomi Terhadap Persepsi Etis Mahasiswa Akuntansi. E-Jurnal Akuntansi, 17(2), 996-1029.

Raharjo, S. T., \& Samuel, H. (2010). Pengaruh Social Media Marketing Terhadap Purchase Intention melalui Brand Awareness Sebagai Variabel Mediasi. Lazada. 1-6.

Rahayuningsih, A. (2016). Analisis Faktor Yang Mempengaruhi Persepsi Mahasiswa Atas Sikap Tidak Etis Akuntan Dengan Love Of Money Sebagai Variabel Moderating. EJurnal Akuntansi, 2016(Oktober), 222.

Rindayanti, R., \& Budiarto, D. S. (2017). Hubungan antara Love of Money, Machiavellian dengan Persepsi Etis: Analisis Berdasarkan Perspektif Gender. Akuntabilitas, 10(2), 261- 
272.

https://doi.org/10.15408/akt.v10i2.6 137

Safitri, K. (2018). Program studi akuntansi fakultas ekonomi dan bisnis universitas muhammadiyah yogyakarta. 2018 (April).

SAPUTRI, D. E. (2018). Hubungan Jenis Kelamin, Pengalaman Magang, Latar Belakang Sosial Ekonomi Dan Love Of Money Dengan Persepsi Etis Mahasiswa Akuntansi. Ekonomi Dan Bisnis, 105(1), 43. Https://Doi.Org/10.1017/Cbo978110 7415324.004

Sari, P. A. (2018). Pengaruh Pendidikan Etika Terhadap Persepsi Etis Mahasiswa Akuntansi. El Muhasaba: Jurnal Akuntansi, $9(2), \quad 38$. https://doi.org/10.18860/em.v11i2.5 270

Sipayung, E. R. (2015). Analisis Pengaruh Aspek Demografi, Status Sosial Ekonomi Dan Pengalaman Kerja Terhadap Persepsi Etis Mahasiswa Akuntansi Dengan Love of Money Sebagai Variabel Intervening (Vol. 4, Issue 2).

Sipayung, E. R., \& Cahyonowati, N. (2015). Analisis Pengaruh Aspek Demografi, Status Sosial Ekonomi Dan Pengalaman Kerja Terhadap Persepsi Etis Mahasiswa Akuntansi Dengan Love of Money Sebagai Variabel Intervening. 4(2), 419-433.

Sugiantari, N., \& Widanaputra, A. (2016). Pengaruh Idealisme, Relativisme, Dan Love of Money Pada Persepsi Mahasiswa Akuntansi Tentang Krisis Etika Akuntan. E-Jurnal Akuntansi, 17(3), 2474-2502.

Sugiyono. (2013). Metode Penelitian Pendidikan Pendekatan Kuantitatif, Kualitatif, dan $R \& D$. Bandung: Alfabeta. 7(2013).

Tang, C. (2016). Income, Money Ethic, Pay Satisfaction, Commitment, and Unethical Behavior: Is the Love of Money the Root of Evil for Hong
Kong Employees. Entomologia Experimentalis et Applicata, 103(3), 239-248. https://doi.org/10.1023/A

Tripermata, L. (2016). Pengaruh Love Of Money, Perilaku Etis Mahasiswa Dan Kecurangan Akuntansi Dengan Gender. Jurnal Ilmiah Ekonomi Global Masa Kini Volume 7 No.01 Desember 2016, 7(1), 55-62.

Wati, M., \& Sudibyo, B. (2016). Pengaruh Pendidikan Etika Bisnis Dan Religiusitas Terhadap Persepsi Etis Mahasiswa Akuntansi. Jurnal Economia, 12(2), 183. https://doi.org/10.21831/economia.v $12 \mathrm{i} 2.11775$

https://kbbi.web.id/magang diakses 2 Agustus 2019 pada pukul 15.30 